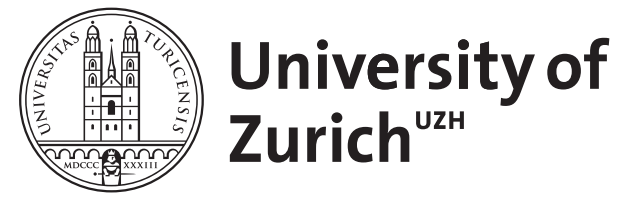

\title{
Archaeology in Times of Scientific Omnipresence
}

\author{
Samida, Stefanie
}

DOI: https://doi.org/10.1515/9783110616651-002

Posted at the Zurich Open Repository and Archive, University of Zurich ZORA URL: https://doi.org/10.5167/uzh-181077

Book Section

Published Version

Originally published at:

Samida, Stefanie (2019). Archaeology in Times of Scientific Omnipresence. In: Brather-Walter, Susanne. Archaeology, History and Biosciences: Interdisciplinary Perspectives. Berlin: de Gruyter, 9-22.

DOI: https://doi.org/10.1515/9783110616651-002 
Archaeology, History and Biosciences 


\section{Ergänzungsbände zum Reallexikon der Germanischen Altertumskunde}

Herausgegeben von

Sebastian Brather, Wilhelm Heizmann

und Steffen Patzold

\section{Band 107}




\section{Archaeology, History and Biosciences}

Interdisciplinary Perspectives

Edited by

Susanne Brather-Walter

\section{DE GRUYTER}


ISBN 978-3-11-061416-9

e-ISBN (PDF) 978-3-11-061665-1

e-ISBN (EPUB) 978-3-11-061417-6

ISSN 1866-7678

Library of Congress Control Number: 2018967103

\section{Bibliografische Information der Deutschen Nationalbibliothek}

Die Deutsche Nationalbibliothek verzeichnet diese Publikation in der Deutschen Nationalbibliografie; detaillierte bibliografische Daten sind im Internet über http://dnb.dnb.de abrufbar.

(c) 2019 Walter de Gruyter GmbH, Berlin/Boston

Satz: Integra Software Services Pvt. Ltd.

Druck und Bindung: $\mathrm{CPI}$ books $\mathrm{GmbH}$, Leck

www.degruyter.com 


\section{Contents}

Foreword - V

Susanne Brather-Walter

Archaeology, History and Biosciences: An Introduction -1

\section{Archaeology and Biosciences}

Stefanie Samida

Archaeology in Times of Scientific Omnipresence - 9

Sabine Deschler-Erb

Pride and Prejudice? On the Relationship Between Archaeology and Biosciences -23

Hélène Réveillas

Archaeothanatology, the Recognition of Funerary Practices: Recent

Examples - 33

\section{Migrations: Mobility and Communication}

Sebastian Schmidt-Hofner

Barbarian Migrations and the Agrarian Economy of the Later Roman Empire in the Fourth Century $\mathrm{CE}-55$

Susanne Brather-Walter

Bow-Brooches as Ethnic Indicators? A Myth of Early Medieval Archaeoloogy — 85

\section{Transformations: Continuity and Discontinuity}

Roland Steinacher

Transformation or Fall? Perceptions and Perspectives on the Transition from Late Antiquity to the Early Middle Ages — 103 
Frans Theuws

Burial Archaeology and the Transformation of the Roman World in Northern Gaul (4th to 6th Centuries) 125

Clémence Hollard and Christine Keyser

Funerary Recruitment and Ancient DNA: Making DNA Speak — 151

\section{Social Structures: Conditions of Life and Social Order}

Magali Coumert

Archaeology vs Written Sources: The Case of Gothic Women - 163

Andrea Czermak

Diet Reconstruction Based on C/N Stable Isotope Analysis: What Can It Contribute to Address Questions on Cultural Change? - 181

Philipp von Rummel

Conclusion and Perspectives 199

Indices

General Index - 205

Index of Geographic Names - 207

Index of Personal Names $2 \mathbf{2 0 9}$ 


\section{Stefanie Samida}

\section{Archaeology in Times of Scientific Omnipresence}

Dedicated to Manfred K. H. Eggert with best wishes for his 75th birthday in May 2016.

"The Anglo-Saxon Invasion: Britain Is More Germanic than It Thinks" - this headline was published in Spiegel Online in June 2011. ${ }^{1}$ The article's German author unequivocally told his readers: "It is now clear that the nation which most dislikes the Germans were once Krauts themselves.” His report was based on recent archaeological and genetic analyses of Anglo-Saxon migration from northern Germany to England. This briefly outlined and public-oriented example can easily be supplemented with other headlines such as "A million Vikings still live among us" or "We Europeans are Asians" ${ }^{3}$ - to name just a few. They all do not only attest to the increasing attention the field of molecular genetics is receiving in public discourse but also represent an observable trend in archaeology which is manifested in an increase of scientific methods. Above all, molecular genetics and isotope analyses have opened up an entirely new approach and apparently uncovered new distinctive evidence regarding human history. The time in which archaeological research projects can be conducted without or only with singular sciences is obviously over. 15 years ago, Ulrich Veit already observed that archaeology is transforming itself increasingly into a kind of "hightech-archaeology", in which the notebook and scientific methods have begun to replace the infamous spade. ${ }^{4}$

Therefore, it should come as no surprise that some researchers have recently been speaking of a "third science revolution" 5 and predicted a paradigm shift questioning if archaeology as a form of 'historical culture studies' (Historische Kulturwissenschaften) could still remain its point of reference. ${ }^{6}$ I will return to these aspects later, but first I would like to determine the relationship between the natural sciences and humanities/

1 See Schulz, Matthias: The Anglo-Saxon Invasion: Britain Is More Germanic than It Thinks (16. 6. 2011). http://www.spiegel.de/international/europe/the-anglo-saxon-invasion-britain-is-more-germanic-thanit-thinks-a-768706.html [29. 1. 2019]. - I am very grateful to Herma Moschner (Clearwater, USA) and Vanessa Bühling (Heidelberg, Germany) for their proofreading; they made this paper more comprehensible - thank you very much.

2 Daily Mail Online, 10th March 2014. See http://www.dailymail.co.uk/news/article-2577003/A-mil lion-Vikings-live-One-33-men-claim-direct-descendants-Norse-warriors.html [29. 1. 2019].

3 Wir Europäer sind Asiaten. Unsere Vorfahren kamen aus dem Osten. Bild der Wissenschaft 2015, H. 7. 4 Veit 2001, 87. - All following German quotes were translated by the author.

5 Kristiansen 2014.

6 Hansen/Nagler 2015.

https://doi.org/10.1515/9783110616651-002 
culture studies $^{7}$ (Geistes-/Kulturwissenschaften) more generally in order to subsequently turn to the current scientistic tendencies in prehistoric archaeology. In doing so, the question of the extent of the domination of the current trend in prehistoric archaeology arises in a way that it increasingly fails to justify its claim of being a 'historical culture study'.

\title{
Humanities and Sciences
}

\begin{abstract}
It would seem, at the present day, as if the relations of the various sciences to one another, in respect of which relationship we have been accustomed to group them together under the name of a universitas litterarum, had become looser than ever. We see the learned men of our day absorbed in studies of detail of such vast extent, that not even the most versatile dare any longer think to string up in his head the varied knowledge pertaining to more than some small district of the domain of modern science. [...] Who shall be able to overlook the whole? - who may hold in his hand the connecting thread, and find his way through the labyrinth? The natural result of all this we first perceive in the fact, that each individual explorer is necessitated to choose for himself a continually narrowing field of inquiry, and can attain but to an imperfect knowledge of adjacent departments of science. ${ }^{8}$
\end{abstract}

This quote is more than 150 years old. The German physicist and polymath Hermann von Helmholtz (1821-1894) uttered these words at the beginning of his academic speech on the occasion of the birthday of the Grand Duke of Baden at the University of Heidelberg in 1862. Helmholtz's address was titled "On the Relation of the Natural Sciences to the Totality of the Sciences" and appears to be, as these opening lines indicate, still quite relevant today. Surely, today no one would agree with his characterization that the humanities are "derived from a process of psychological intuitions"'; the same applies to his enthusiastic eulogy of historians' memory with which they amazed their contemporaries, ${ }^{10}$ while physicists and mathematicians do not need any memory, here defined as a kind of mental activity, that is based on analogies. ${ }^{11}$ However, Helmholtz's statements are still relevant when the relationships between the disciplines are concerned: "The physicist", as he put it, "will find some difficulty in imparting to the philologist and the jurist a clear view of a complicated process of nature. [...] The philologist and the historian [...] will find the physicist surprisingly indifferent to literary treasures; perhaps even more indifferent than is good for the history of his own science". ${ }^{12}$

7 From now on I will use the terms 'humanities' and 'culture studies' as synonyms.

8 Helmholtz 1869, 5ff. The original German version was published 1862, see Helmholtz 1862.

9 Helmholtz 1869, 14.

10 Helmholtz 1869, 14.

11 Helmholtz 1869, 18.

12 Helmholtz 1869, 9. 
Nearly 100 years earlier than Charles Percy Snow's famous lecture "The Two Cultures" (1959), ${ }^{13}$ Helmholtz's representation of the relationship between natural scientists and scholars of humanities described the reciprocal incomprehension of these groups, which Snow called literary intellectuals and scientists. Snow was much more pronounced in his language and spoke of the antipathy and a lack of understanding that shapes everyday life, which leads to distorted images of each other. ${ }^{14}$ More clearly than Helmholtz, he pointed to the deprecation of sciences in society and provided the Second Law of Thermodynamics as an example:

A good many times I have been present at gatherings of people who, by the standard of the traditional culture, are thought highly educated and who have with considerable gusto been expressing their incredulity at the illiteracy of scientists. Once or twice I have been provoked and have asked the company how many of them could describe the Second Law of Thermodynamics. The response was cold: it was also negative. Yet I was asking something which is about the scientific equivalent: Have you read a work of Shakespeare $?^{15}$

In this context, it is irrelevant what Snow intended to convey with this readily and much-quoted example; certainly, his lecture must be seen against the backdrop of the so-called Sputnik Shock (1957) and the quote is obviously an inappropriate comparison, consciously emphasizing the gap between the disciplines. ${ }^{16}$ Yet I argue that Snow would have received similar answers or uncomprehending looks if he would have asked about the more common Theorem of Pythagoras or Newton's Law of Gravity. Moreover, I am also sure that the situation he described could be found in a similar form today. This gap was not only conjured up in his time but was already a topic of critical reflection as attested to, among others, in Helmholtz's speech in $1862 .^{17}$

13 Snow 1959/1998.

14 "Literary intellectuals at one pole - at the other scientists, and as the most representative, the physical scientists. Between the two a gulf of mutual incomprehension - sometimes (particularly among the young) hostility and dislike, but most of all lack of understanding. They have a curious distorted image of each other. Their attitudes are so different that, even on the level of emotion, they can't find much common ground" (Snow 1959/1998, 4).

15 Snow 1959/1998, 14f. - In his consciously polemic article about the two cultures, the German science historian Ernst-Peter Fischer $(1991,4)$ put the problem in a nutshell: "I am convinced that many people neither know Shakespeare's sonnet nor the Second Law of Thermodynamics. Nevertheless most of them would contemptuously deride people who admit not knowing the poems, and consider them to be uneducated (ungebildet) while simultaneously welcoming those who do not know the Second Law of Thermodynamics into their peer group."

16 To this see Oels 2015.

17 See also Dilthey 1883; Rickert 1926. 
Since Snow's description of the mutual ignorance of the two academic cultures, the debate of the 'two cultures' thesis has picked up speed ${ }^{18}$ and led to an intensive engagement. ${ }^{19}$ The German philosopher and historian of science Jürgen Mittelstraß, for instance, considers Snow's 'two cultures' thesis to not only be a myth but also a curse that has particularly burdened the humanities ${ }^{20}$ because, according to Snow, the future is to a certain extent intrinsic to the sciences whereas the humanities merely look back into the past. ${ }^{21}$ In other words: while sciences seem future-oriented, the humanities appear to be disciplines looking backward.

It is not my aim to continue the entire discussion of Snow's 'two cultures' thesis which occurred primarily at the end of the 1980s and has continued to flare up into the present. ${ }^{22}$ Instead, I would like to demonstrate that the different perception of the two cultures respectively of "bed and table"23 was clearly introduced long before Snow and in a similarly pronounced way by Hermann von Helmholtz. I claim that this pair of antagonisms is still a strong element of our academic world $^{24}$ even if some researchers have rightly pointed out recently that the "'battle of academic cultures' [...] inadequately describes the present situation", because the economic criteria of differentiation - money-generating versus money-wasting sciences - apply nowadays. ${ }^{25}$

In his speech, Helmholtz observed that despite the faith in progress and the quick developments in the field of science, the natural sciences were also under pressure one had accused them of having taken an isolated path and being estranged from the other sciences ${ }^{26}$ - and thus, he promoted a "union of the different sciences" on the ground that every one-sided training is flawed. It renders researchers of all kinds unprepared for the types of activities practiced less, it limits the "comprehensive

18 For example Kreuzer 1987; Bachmaier/Fischer 1991; see also the introduction by Stefan Collini in Snow 1959/1998.

19 Occasionally it came to polemical attacks against Snow, see the Richmond Lecture of Frank Raymond Leavis in 1962 (Leavis 2013).

20 Mittelstraß 1989, 1991.

21 Snow 1959/1998, 11.

22 See, e.g., Eggert 2006, 11 ff.

23 Mittelstraß 1991, 11.

24 Eggert 2006, 18. - This is well illustrated by the ongoing, often quite passionate discussion. Holzhey 1999, 50 expresses it somewhat dramatically as follows: "The relationship between the sciences and the humanities can be defined as one of mutual critizism. Within this context of confrontation, both sides struggle to determine our future world's cultural form."

25 Hartmann et al. 2012, 9.

26 Helmholtz 1869, 7: "I am the rather drawn to take up the question of the connection of the various sciences as I myself belong to the department of the natural sciences; and this department has been charged, of late, with having, more than any other of the sciences, struck out for itself an independent path, and become estranged from the rest, which, by common philological and historical studies, are connected with one another.” 
views of a subject" and could easily lead to an "overweening self-esteem". ${ }^{27}$ Certainly, his speech was shaped by the dichotomy of sciences and humanities, but at the same time it is entirely visionary in its plea for collaboration since all sciences ultimately have a common goal, namely "to assert the predominance of mind over the world of matter". ${ }^{28}$ This may sound somewhat extreme but it hits the mark since every single science aims first and foremost for knowledge or pursues an epistemic goal. However, a further question arises: does Helmholtz's 'meta'-goal suffice in order to reach a productive cooperation? Spontaneous reactions might be disapproving. Inevitably, much more is needed to pursue a collaboration profitable for all. The 'magic' word in this context is 'interdisciplinarity'.

\section{On Interdisciplinarity}

Some terminological clarification appears to be appropriate here. ${ }^{29}$ Four different modes of doing research became generally agreed on: monodisciplinarity, multidisciplinarity, interdisciplinarity and transdisciplinarity. They are differentiated first by the number of disciplines involved, second by the form of input needed to solve a given problem and third by the degree of integration achieved in the process of cooperation (Tab. 2.1).

Interdisciplinarity implies that the problem to be solved is analyzed and defined jointly as well as that each discipline brings in its particular perception of the task and the possible ways of solving it. This leads to a discussion of both the conceptional frame of reference and the procedure; whenever necessary, this discussion will be continued as a more or less institutionalized structure throughout the whole process of research. In other words, this mode of collaborative research hinges on a continuous exchange of ideas, insights and results as long as the investigation proceeds, or as Mark Pollard and Peter Bray once expressed it: "It has to be an equal partnership, with mutually intelligible language of communication, agreed objectives, and equal inputs". ${ }^{30}$ To put it briefly, there can be no interdisciplinarity without a genuine

27 Helmholtz 1869, 10.

28 Helmholtz 1869, 22.

29 Some of the following mentioned aspects on interdisciplinarity were already discussed in detail, see Samida/Eggert 2012.

30 Pollard/Bray 2007, 246. Quite similar a few pages further on: "There are three fundamental keys to successfully riding the bicycle. One is a common goal [...], secondly a shared language, and the third, mutual respect - not simply personal respect, which is a sine qua non, but mutual academic respect. [...] Communication over a carefully defined question is the key. Integration cannot be defined just by the quantity of joint papers: It comprises discussion, meetings, conferences, and negotiation" (Pollard/Bray 2007, 255f.). 
Tab. 2.1: Multi-, inter- and transdisciplinarity (based on Eggert 2011, 39 fig. 3).

\begin{tabular}{|c|c|c|c|}
\hline & Multidisciplinarity & Interdisciplinarity & Transdisciplinarity \\
\hline Methods & $\begin{array}{l}\text { Discipline-specific } \\
\text { methods; no } \\
\text { cooperation }\end{array}$ & $\begin{array}{l}\text { Discipline-specific } \\
\text { methods; high degree of } \\
\text { cooperation }\end{array}$ & $\begin{array}{l}\text { Joint development of new methods; } \\
\text { disciplines merge (at least partially) } \\
\text { during a certain time span }\end{array}$ \\
\hline $\begin{array}{l}\text { Problem } \\
\text { Definition }\end{array}$ & $\begin{array}{l}\text { Discipline-specific } \\
\text { problem }\end{array}$ & Jointly defined problem & $\begin{array}{l}\text { New and jointly defined problems } \\
\text { (new fields of research) }\end{array}$ \\
\hline $\begin{array}{l}\text { Language, } \\
\text { Terms, } \\
\text { Theories }\end{array}$ & Discipline-specific & $\begin{array}{l}\text { Discussion, clarification } \\
\text { and consolidation of the } \\
\text { conceptual frame }\end{array}$ & $\begin{array}{l}\text { Development of a new conceptual } \\
\text { frame }\end{array}$ \\
\hline $\begin{array}{l}\text { Gain of } \\
\text { Knowledge }\end{array}$ & $\begin{array}{l}\text { Basically discipline- } \\
\text { specific; } \\
\text { nevertheless, each } \\
\text { discipline } \\
\text { participates }\end{array}$ & $\begin{array}{l}\text { Additional gain of } \\
\text { knowledge through close } \\
\text { cooperation }\end{array}$ & $\begin{array}{l}\text { Autonomous gain of knowledge; } \\
\text { only possible through developing } \\
\text { new methods }\end{array}$ \\
\hline Summary & $\begin{array}{l}\text { Parallel existence of } \\
\text { disciplines; minimal } \\
\text { cooperation }\end{array}$ & $\begin{array}{l}\text { Continuous exchange of } \\
\text { ideas, insights and } \\
\text { results between } \\
\text { disciplines on a common } \\
\text { basis }\end{array}$ & $\begin{array}{l}\text { Boundaries of disciplines become } \\
\text { blurry and might even dissolve } \\
\text { partially; disciplines merge } \\
\text { temporary; possible emergence of } \\
\text { new disciplines }\end{array}$ \\
\hline
\end{tabular}

reflection on theories and methods in each of the participating disciplines. Yet, this is the most basic prerequisite.

However, 'pretension and reality' of interdisciplinarity are not always congruent. This holds also true for a few cases of reflections on interdisciplinarity already published. Veronika Fuest who initialized and coordinated a German Collaborative Research Center (Sonderforschungsbereich) uniting scientists and institutions for many years, concludes that there are usually more problems than successes within interdisciplinary collaborations, especially between social sciences (including the humanities) and natural sciences. This is due to the fact that both epistemology and methodology are not only fundamentally different but, in addition, rarely understood by the respective partners. ${ }^{31}$ According to Fuest, there are four problems: (1) differences in the epistemology of the participating disciplines; (2) differences in data

31 Fuest 2006, 47ff. Moreover, on the practical level this kind of research fails because of mutual prejudices; this is especially true for joint projects of the sciences and the humanities, where the latter with their qualitatively oriented mode of research often have to 'fight' for being accepted by their quantifying colleagues (Fuest 2006, 62). Instructive examples of prejudices and mutual misunderstandings are given by Egorova (2010). 
acquisition and analysis; (3) difficulties in the project's organization and management; and (4) difficulties concerning the institutional frame (e.g., introduction of interdisciplinary approaches into university teaching, creation of new funding lines, training of referees). ${ }^{32}$

Fuest's insights are not isolated. Quite to the contrary, as many practitioners of interdisciplinary cooperation who have critically reflected on this kind of research agree with her. Thus, the contributions to the volume Interdisziplinarität: Praxis Herausforderung - Ideologie edited by Jürgen Kocka mention a variety of problems in the context of 'genuine' interdisciplinarity. ${ }^{33}$

\section{Archaeology and Sciences}

To avoid any misunderstanding, let me state from the outset that it is neither my intention to declare collaborative cooperations between natural sciences and humanities as essentially impracticable, nor to lament the increasing role of the natural sciences in archaeology or raise a philippic against the natural sciences in the context of archaeological research in general in the following paragraphs. Considering the long tradition of collaboration between archaeology and various natural sciences, this would be more than an escapistic view. For German-speaking prehistoric archaeology, Rudolf Virchow (1821-1902) was not only one of the most famous epigones but also the central protagonist who at the time gave the young and developing discipline a more naturalscientific orientation. In this context, one speaks of a "scientific paradigm" 34 which could be seen in its largely material-oriented alignment of the early studies and which was closely connected with Virchow and his activities, e.g. the founding of Berlin Anthropological Society (Berliner Gesellschaft für Anthropologie, Ethnologie und Urgeschichte) in 1869. Virchow preferred only 'facts' and was of the opinion that prehistoric archaeology could be practiced with pure scientific methods. ${ }^{35}$ Quite instructive in this context is his preface in Heinrich Schliemann's famous book Ilios. The City and Country of the Trojans (1880) in which he characterized himself as a "naturalist habituated to the most dispassionate objective contemplation (mit der Gewohnheit der kältesten Objektivität)". ${ }^{36}$

\footnotetext{
32 Fuest 2004, 6. - Similar problems are discussed in other critical reports on interdisciplinary research projects: Immelmann 1987; Voßkamp 1987; Lentz 2004; Meier-Tillessen (2011) with reference to so-called Research Training Groups (Graduiertenkollegs).

33 See Kocka 1987.

34 Eggert 2006, 46.

35 Andree 1976, 169, writes: "Virchow's effort to practice and promote strong scientific research based on facts and to refuse any kind of speculation was exemplarily."

36 Virchow 1880, IX.
} 
Thus, from the very beginning, prehistoric archaeology was closely connected both with scientific methods and a scientific approach to the past. The relevance of new scientific methods has also been repeatedly emphasized by prehistoric archaeologists. ${ }^{37}$ In recent years it is particularly Kristian Kristiansen, who discussed this subject quite intensively. ${ }^{38}$ For this reason and as a representative of other opinions, I would like to outline his views on this field of research in greater detail.

Kristiansen points out that there are both periods of innovation and periods of consolidation in prehistoric archaeology. ${ }^{39}$ For the former, the ensuing features are characteristic: great influence of natural sciences, implementation of new scientific methods, international collaboration and research in aspects of global questions. Periods of consolidation in turn are characterized by a minimal influence of natural sciences, recourse to proven scientific methods and familiar knowledge, national research networks and studies of mainly local problems. Against this backdrop, he recognizes two periods of innovation: the first one lasted from 1850 to 1860 , the second period lies between 1940 and 1950. Thus, the first boost to innovation is evident at the beginning of archaeological research itself and was shaped by the previously stated cooperation of physical anthropology, cultural anthropology/ethnology, archaeology, geology and zoology. The second period of innovative improvements was shaped by developments in the field of pollen analyses, particularly by the introduction of the radiocarbon method which revolutionized dating methods. Kristiansen asks if we are again in such a period of innovation, answering this question in his 2011 article with a cautious 'yes' since the first signs of these changes can already be observed (new scientific methods, questions of global extent/dimension, e.g. migration).

In a recent article from 2014 his still cautious appraisal gave way to a definite statement. ${ }^{40}$ Kristiansen now observes a paradigm shift and speaks of a "third science revolution", which manifests itself in the increase of "big data", "quantification and modeling" and "theoretical power of new knowledge"; the development and inclusion of scientific methods (especially genetics) play the central role in his argument. Hardly surprising, his paper led to some critical reactions. ${ }^{41}$ In one of the comments to Kristiansen's article in Current Swedish Archaeology Elisabeth Niklasson countered: "Big Data does not mean better data; after all it is often just the same data linked up. It makes 'bigger' interpretations possible, which is great, but this does not equal 'better' interpretations. And importantly, just because it is true, it does not mean it is right." ${ }^{22}$ Quite similar is a statement by Alfredo González-

37 For example Renfrew/Boyle 2000; Renfrew 2010; Gramsch/Lüth 2010.

38 Kristiansen 2008, 2011, 2014.

39 Kristiansen 2008, 11ff.; 2011, 73f.

40 Kristiansen 2014.

41 See the various comments of Kristiansen's paper in Current Swedish Archaeology 2014; also: Lidén/ Eriksson 2013; Meier 2008.

42 Niklasson 2014, 62. 
Ruibal, who is extremely critical of Kristiansen's "paradigmatic enthusiasm". ${ }^{43}$ I would like to give just one of González-Ruibal's examples which refers to Kristiansen's exclusive argumentation. What Kristiansen emphasized as the revolution, González-Ruibal stresses, might be at best proclaimed $a$ revolution; furthermore, in González-Ruibal's opinion there should still be the chance of practicing a different form of archaeology. ${ }^{44} \mathrm{He}$ cautions against a sort of 'two-class-archaeology': the good one, which uses scientific methods, and the 'inferior' one, which can be practiced without using DNA analyses and isotope databases. And he rightly asks: "will I be allowed to do my archaeology under the new revolutionary regime?". ${ }^{45}$

Kristiansen's hymn is quite odd. This is true for his belief concerning big data as well as his belief in the scientific material itself which could tell us, as he believes, whole life stories if only the samples would be sampled in a correct manner:

Like now: we can once again walk back into the museum stores and select material that will tell us whole life stories of individuals, their diet, mobility and close family stories, as well as their larger genetic family stories from prehistory until the present. A new door has been opened to previously hidden absolute knowledge that once again will reduce the amount of qualified guessing and thus both refine and redefine theory and interpretation. ${ }^{46}$

Considering such a statement, one has to ask oneself: which "whole life histories" does he mean? Does he mean aspects which concern what early men looked like, their whereabouts and the genetic kinship in prehistoric times? ${ }^{47}$ Results regarding such questions might please one or the other and eventually satisfy one's own epistemic interest; however, the results are only peripherally interesting for culture scientists and archaeologists. Instead, one has to ask: what does it mean when we talk of kinship in Neolithic or Iron Age times? Genetic kinship is obviously not the same as social kinship this is well established by anthropological and sociological studies. ${ }^{48}$ Kinship - and here, I do not want to use it in a culturalistic way - is a complex field which does not only apply to the so-called patchwork families of our time. ${ }^{49}$ Moreover, Kristiansen's eulogy

43 González-Ruibal 2014, 41.

44 González-Ruibal 2014, 43.

45 González-Ruibal 2014, 44.

46 Kristiansen 2014, 27.

47 Quite similar González-Ruibal (2014) who emphasizes that archaeometry seduces "laziness". Why, he sneered, should one try to think more intensive and more different when all the new methods tell us "how the past actually was? They tell us exactly what they ate, where they came from, which diseases they suffered from. What else do we need?”

48 See Bargatzky 1997, 96ff.; Schmidt 2006; Schnegg et al. 2010.

49 See also Müller's (2013) appraisal: “Obviously, the recent debate about aDNA methods lacks a link to social and cultural theories on the construction of identities and societies. If we read palaeogenetic research articles, the impression often arises that haplotypes are responsible for why certain individuals were together with whom and why not. [...] From the discourse about 'sex and gender' we already know that social roles are social products and not necessarily biologically distinct. Human societies are human made and not biologically determined." 
conceals that we still do not know very much about the manner in which people lived together, for instance, in the Bronze Age (e.g. settlement type, social structure), furthermore: are scientific results helpful regarding the question which structure of society prevailed during the Hallstatt period? How did people live 2500 years ago? With whom und how did they exchange goods? What conceptions did they have concerning this world and the hereafter? Which rituals did they practice (both sacred and profane)? What religious beliefs did they have ${ }^{50}$ In short: all of these central questions and many others cannot be answered by using more and more scientific samples starting with pollen and metal samples (e.g. analyses of origin) to isotope and DNA analyses. Not everything that is technically possible is relevant. Furthermore, as also becomes evident in Elisabeth Niklasson's criticism, one cannot help but feel that many of the so-called hard facts are anything but hard facts. ${ }^{51}$ While this is also the message communicated by natural scientists, it does not always reach their archaeological colleagues. Not infrequently, archaeologists accept the 'hard facts' uncritically and hastily link these facts with cultural-historical interpretations. ${ }^{52}$ However, the scientific data also needs to be examined critically and in order to do so it is necessary to know and above all to understand the prevailing scientific methodology. But in view of growing specialization this can hardly be achieved. At this point, we have once again arrived at Hermann von Helmholtz.

\section{Archaeology in Times of Scientific Omnipresence: What Are We Left With?}

Thus can we observe, in accordance with Kristiansen, a boost to innovation and a "scientific revolution" in archaeology today? Or should we agree with the art historian and philosopher Wolfgang Kemp, who speaks pessimistically of "waves of naturalism" 53 which seize the humanities from time to time, and in which the humanities transfer their leading concepts to the sciences in order to answer their own questions? I will leave it up to you to answer these questions.

50 "'Hard sciences”, as the literary and media scholar Jochen Hörisch $(2004,318)$ puts it sarcastically "cannot contribute to solving conflicts induced by religion - not even if they were to discover areas in the brain in which religious competences are located."

51 See also Niklasson 2014.

52 Quite similar Schreg 2014, 732. All at once this applies to the sciences too as Hagner and Rheinberger (2002, 23) elucidate: "Due to symmetrical reasons, one, however, has to expect the natural sciences to not succumb to the arrogance of facts and the naively belief that they have always been connected to the nature outside - and therefore are in a stronger position than the social sciences."

53 Kemp 2006, 719; see also Hagner/Rheinberger 2002, 17f. 
In a workshop report, Svend Hansen and Anatoli Nagler recently pointed out that "the times, in which one could have used singular sciences just as a possible supplement or not" are over; everyone who digs needs to use all methods which are relevant for interpreting the site. ${ }^{54}$ Everyone, I guess, would agree with them in this context without any reservation. I am however much more skeptical regarding their other conclusions since they question "if archaeology as historical culture science could remain the obligatory point of reference". "Certainly", I would like to answer. Archaeology attempts to answer historical respectively cultural historical questions and in doing so integrates all available sources; this includes all knowledge gained by scientific methods. ${ }^{55}$ Therefore real interdisciplinary collaboration is essential even if new difficulties on the epistemological, as well as on the structural, institutional and actor-centered level will need to be overcome anew. More than ever before, a discourse between the natural and the cultural scientists is needed. ${ }^{56}$

In the context of historical culture studies and thereby in an archaeological context, the natural sciences are, at best, only one side of the coin. In other words, there is much more to archaeology than any natural science can ever provide. However important the insights that the natural sciences may provide, they need to be evaluated in an archaeological and cultural historical frame of reference. ${ }^{57}$

In his article titled "Wissenschaft, Geisteswissenschaft, Philosophie" ("Science, Humanities, Philosophy”), the philosopher Dirk Hartmann ${ }^{58}$ recently emphasized the importance of the humanities, or rather culture sciences; he said: "Whoever stopped to reflect on his/her culture will soon not understand it any longer. Whoever has stopped to understand her/his culture will lose it”. There is nothing more to add.

\section{References}

Andree, Christian, Rudolf Virchow als Prähistoriker 1. Virchow als Begründer der neueren deutschen Ur- und Frühgeschichtswissenschaft (Köln, Wien 1976).

Bachmaier, Helmut/Fischer, Ernst Peter (eds.), Glanz und Elend der zwei Kulturen. Über die Verträglichkeit der Natur- und Geisteswissenschaften. Konstanzer Bibliothek 16 (Konstanz 1991).

54 Hansen/Nagler 2015.

55 See Eggert 2006, 25.

56 See, for example, Egorova (2010) in general and Samida/Eggert (2013) on the focus of prehistoric archaeology.

57 Relating to a growing 'market' of genetic research see also Goodman (2007, 229), who explains: "Genetics knowledges, discourses, and practices are too important, too determinative, to escape critical study. What is needed is not an age of genetics but an age of anthropology to think through the localness, partiality, instability, and context of genetic information. Genetics need anthropology to help fashion its questions and to make sense of its results."

58 Hartmann 2012, 25. 
Bargatzky, Thomas, Ethnologie. Eine Einführung in die Wissenschaft von den urproduktiven Gesellschaften (Hamburg 1997).

Dilthey, Wilhelm, Einleitung in die Geisteswissenschaften. Versuch einer Grundlegung für das Studium der Gesellschaft und der Geschichte 1 (Leipzig 1883).

Eggert, Manfred K. H., Archäologie. Grundzüge einer Historischen Kulturwissenschaft (Tübingen, Basel 2006).

Eggert, Manfred K. H., Archäologie - Historie - Philologie. Überlegungen zur Disziplinarität in den Altertumswissenschaften. In: Methodik und Didaktik in der Ägyptologie. Herausforderungen eines kulturwissenschaftlichen Paradigmenwechsels in den Altertumswissenschaften, ed. Alexandra Verbovsek/Burkhard Backes/Catherine Jones. Ägyptologie und Kulturwissenschaften 4 (München 2011) 31-52.

Egorova, Yulia, DNA evidence? The impact of genetic research on historical debates. BioSocieties $5 / 3,2010,348-365$.

Fischer, Ernst Peter, Shakespeares Sonette und der Zweite Hauptsatz der Thermodynamik. Ein polemischer Beitrag zu den zwei Kulturen. In: Bachmaier/Fischer 1991, 45-62.

Fuest, Veronika, Anspruch und Wirklichkeit interdisziplinärer Zusammenarbeit in der deutschen Umweltforschung. Epistemologische, organisatorische und institutionelle Aspekte (2004). URL http://www.heidelberger-lese-zeiten-verlag.de/archiv/online-archiv/fuestneu.pdf [21. 1. 2019].

Fuest, Veronika, Ethnologen in der Arena: Ein akteursanalytischer Blick in Umweltforschungsprojekte. Sociologus 56/1, 2006, 35-67.

González-Ruibal, Alfredo, Archaeological revolution(s). Current Swedish Archaeology 22, 2014, 41-45.

Goodman, Alan H., Toward genetics in an era of anthropology. American Ethnologist 34/2, 2007, 227-229.

Gramsch, Alexander, Different languages. An interview on archaeology in Germany with Friedrich Lüth. Archaeological Dialogues 17/2, 2010, 199-214.

Hagner, Michael/Rheinberger, Hans-Jörg, Die Zukunft der Geisteswissenschaften und die Wissenschaftsgeschichte. In: Wissenschaftsgeschichte und Geschichtswissenschaft. Aspekte einer problematischen Beziehung. Wolfgang Küttler zum 65. Geburtstag, ed. Stefan Jordan/ Peter T. Walther (Waltrop 2002) 17-23.

Hansen, Svend/Nagler, Anatoli, International symposium multidisciplinary methods in archaeology. Latest updates and outlook, 22. 6. 2015-26. 6. 2015 Novosibirsk. H-Soz-Kult, 18. 9. 2015. URL http://www.hsozkult.de/conferencereport/id/tagungsberichte-6162 [21. 1. 2019].

Hartmann, Dirk, Wissenschaft, Geisteswissenschaft, Philosophie. In: Methoden der Geisteswissenschaften. Eine Selbstverständigung, ed. Dirk Hartmann/Amir Mohseni/Erhard Reckwitz/Tim Rojek/Ulrich Steckmann (Weilerswist 2012) 17-32.

Hartmann, Dirk/Mohseni, Amir/Rechwitz, Erhard/Rojek, Tim/Steckmann, Ulrich, Einleitung. In: Methoden der Geisteswissenschaften. Eine Selbstverständigung, ed. Dirk Hartmann/Amir Mohseni/Erhard Rechwitz/Tim Rojek/Ulrich Steckmann (Weilerswist 2012) 7-14.

von Helmholtz, Hermann, Ueber das Verhältnis der Naturwissenschaften zur Gesammtheit der Wissenschaften. Rede zum Geburtstagsfeste des höchstseligen Grossherzogs Karl Friedrich von Baden und zur akademischen Preisvertheilung am 22. November 1862 (Heidelberg 1862). URL http://www.ub.uni-heidelberg.de/archiv/11487 [21. 1. 2019].

von Helmholtz, Hermann, On the relation of the natural sciences to the totality of the sciences. An address delivered before the University of Heidelberg, translated by C. H. Schaible (London 1869). URL http://www.ub.uni-heidelberg.de/archiv/12693 [21. 1. 2019].

Holzhey, Helmut, Natur- und Geisteswissenschaften - zwei Kulturen? In: Kulturwissenschaften. Positionen und Perspektiven, ed. Johannes Anderegg/Edith Anna Kunze (Bielefeld 1999) 31-50. 
Hörisch, Jochen, Theorie-Apotheke. Eine Handreichung zu den humanwissenschaftlichen Theorien der letzten fünfzig Jahren, einschließlich ihrer Risiken und Nebenwirkungen (Frankfurt a. M. 2004).

Immelmann, Klaus, Interdisziplinarität zwischen Natur- und Geisteswissenschaften - Praxis und Utopie. In: Kocka 1987, 82-91.

Kemp, Wolfgang, "Natürlich". Die Geisteswissenschaften in Zeiten biologischer Korrektheit. Neue Rundschau 117/2, 2006, 71-86.

Kocka, Jürgen (ed.), Interdisziplinarität. Praxis - Herausforderung - Ideologie (Frankfurt a. M. 1987).

Kreuzer, Helmut (ed.), Die zwei Kulturen. Literarische und naturwissenschaftliche Intelligenz.

C. P. Snows These in der Diskussion (München 1987) [First published: Stuttgart 1969].

Kristiansen, Kristian, Do we need the 'archaeology of Europe'? Archaeological Dialogues 15/1, 2008, $5-25$.

Kristiansen, Kristian, Theory does not die it changes direction. In: The death of archaeological theory?, ed. John Bintliff/Mark Pearce (Oxford 2011) 72-79.

Kristiansen, Kristian, Towards a new paradigm? The third science revolution and its possible consequences in archaeology. Current Swedish Archaeology 22, 2014, 11-34.

Leavis, Frank Raymond, Two cultures? The significance of C. P. Snow. With introduction by Stefan Collini (Cambridge 2013).

Lentz, Carola, Interdisziplinarität. Erfahrungen und Probleme. In: Mensch und Natur in Westafrika. Ergebnisse aus dem Sonderforschungsbereich 268 'Kulturentwicklung und Sprachgeschichte im Naturraum westafrikanische Savanne', ed. Klaus-Dieter Albert/Doris Löhr/Katharina Neumann (Weinheim 2004) 30-37.

Lidén, Kerstin/Eriksson, Gunilla, Archaeology vs. archaeological science. Do we have a case? Current Swedish Archaeology 21, 2013, 11-20.

Meier, Thomas, There is no archaeology but European archaeology... Archaeological Dialogues 15/1, 2008, 34-36.

Meier, Thomas/Tillessen, Petra (eds.), Über die Grenzen und zwischen den Disziplinen. Fachübergreifende Zusammenarbeit im Forschungsfeld historischer Mensch-Umwelt-Beziehungen (Budapest 2011).

Mittelstraß, Jürgen, Glanz und Elend der Geisteswissenschaften. Oldenburger Universitätsreden 27 (Oldenburg 1989).

Mittelstraß, Jürgen, Geist, Natur und die Liebe zum Dualismus. Wider den Mythos von zwei Kulturen. In: Bachmaier/Fischer 1991, 9-28.

Müller, Johannes, Kossinna, Childe and aDNA. Comments on the construction of identities. Current Swedish Archaeology 21, 2013, 35-37.

Niklasson, Elisabeth, Shutting the stable door after the horse has bolted. Critical thinking and the third science revolution. Current Swedish Archaeology 22, 2014, 57-63.

Oels, David, “Den Zweiten Hauptsatz der Thermodynamik angeben”. Zu einem unpassenden Beispiel in C. P. Snows Zwei Kulturen. Arbeitsblätter Sachbuchforschung 25 (Mainz 2015). URL https:// www.blogs.uni-mainz.de/fb05-sachbuchforschung/files/2015/07/Oels_Zu_Snow_Zwei_ Kulturen.pdf [21.1.2019].

Pollard, A. Mark/Bray, Peter, A bicycle made for two? The integration of scientific techniques into archaeological interpretation. Annual Review of Anthropology 36, 2007, 245-259.

Renfrew, Colin, Archaeogenetics - towards a 'new synthesis'? Current Biology 20, 2010, R162-R165. Renfrew, Colin/Boyle, Katie (eds.), Archaeogenetics. DNA and the population prehistory of Europe (Cambridge 2000).

Rickert, Heinrich, Kulturwissenschaft und Naturwissenschaft. Sechste und siebte durchgesehene und ergänzte Auflage (Tübingen 1926) [First published 1899]. 
Samida, Stefanie/Eggert, Manfred K. H., Über Interdisziplinarität: Betrachtungen zur Kooperation von Natur- und Kulturwissenschaften in der Archäologie. Hephaistos 29, 2012, 9-24.

Samida, Stefanie/Eggert, Manfred K. H., Archäologie als Naturwissenschaft? Eine Streitschrift. Reihe Pamphletliteratur 5 (Berlin 2013).

Schmidt, Johannes F. K., Das Verhältnis von sozialer und biologischer Verwandtschaft: Konkurrenz oder Symbiose biologischer und soziologischer Konzepte? In: Die Natur der Gesellschaft. Verhandlungen des 33. Kongresses der Deutschen Gesellschaft für Soziologie in Kassel 2006, ed. Karl-Siegbert Rehberg (Frankfurt a. M. 2008) 894-908. URN http://nbn-resolving.de/urn: nbn:de:0168-ssoar-153014 [21. 1. 2019].

Schnegg, Michael/Pauli, Julia/Beer, Bettina/Alber, Erdmute, Verwandtschaft heute: Positionen, Ergebnisse und Forschungsperspektiven. In: Verwandtschaft heute. Positionen, Ergebnisse und Perspektiven, ed. Erdmute Alber/Bettina Beer/Julia Pauli/Michael Schnegg (Berlin 2010) 7-44.

Schreg, Rainer, Review of Meier/Tillessen 2011. European Journal of Archaeology 17/4, 2014 , 728-732.

Snow, Charles Percy, The two cultures. The Rede lecture (1959). In: Charles Percy Snow, The two cultures. With introduction by Stefan Collini (Cambridge 1998) 1-51.

Veit, Ulrich, Von der Schwierigkeit ein Fach zu bestimmen. Überlegungen zur kognitiven Identität der Ur- und Frühgeschichtsforschung. Saeculum 52/1, 2001, 73-90.

Virchow, Rudolf, Preface. In: Heinrich Schliemann, Ilios. the city and country of the Trojans (London 1880) IX-XVI.

Voßkamp, Wilhelm, Interdisziplinarität in den Geisteswissenschaften (am Beispiel einer Forschungsgruppe zur Funktionsgeschichte der Utopie). In: Kocka 1987, 92-105. 